\title{
SHRIMP zircon ages of orthogneiss from EW-trending gneissic domes in Southern Tibet: Their tectonic implications
}

\author{
Yu Wang* and Wencan Liu \\ Geologic Laboratories Center and Department of Geology, China University of Geosciences, Beijing 100083, CHINA \\ * To whom correspondence should be addressed.E-mail: wangyu196601@sohu.com
}

The north Himalayan gneissic domes consist of several metamorphic and plutonic culminations that extend $\sim 650-700$ $\mathrm{km}$ in east-west direction. These orthogneissic domes are mantled by high-grade metamorphic rocks (Lee et al. 2000, 2004; Burchfiel et al. 1992), and in turn, are mantled by low-grade metamorphic to unmetamorphosed rocks. Five zircon SHRIMP samples, collected from the E-W trending gneissic domes, present similar ages on the western part of domes at 37-28 Ma and none of these ages on the eastern part correspond to rim of single grain. The core of the single grain yielded similar age of $\sim 530-480 \mathrm{Ma}$. Besides, CL photographys also reveal different features for those five samples.

\section{Kangmar Dome}

Two samples contain zircons that exhibit sector zoning and welldefined low-U cores. Most crystals have intermediate U rims. Core and rim analyses of single zircons give identical ages. Of the 22 analyses, most of them fall within a single group that spreads slightly along the Concordia and constitute a coherent group, yielding a mean ${ }^{206} \mathrm{~Pb} /{ }^{238} \mathrm{U}$ age of $\sim 530-520 \mathrm{Ma}$. This weighted mean age is interpreted to be the crystallizing age of zircon, which can be referred to constrain the age of the orthogneiss, its former granite.

\section{Mabja Dome}

Thirteen analyses on 12 zircon grains or fragments were performed. Of these, 13 analyses constitute no coherent group, but yield a weighted mean ${ }^{206} \mathrm{~Pb} /{ }^{238} \mathrm{U}$ age of $\sim 502 \mathrm{Ma}$ (8 data). This weighted mean age is interpreted to be the crystallizing age of zircon. Most of zircons from these samples bear oscillatory zoning, and crystallized during the magmatic event in which the granite formed.

\section{Lagri-Kangri Dome}

Twentyeight analyses on 25 zircon grains or fragments were performed whose ages range from $\sim 36 \mathrm{Ma}$ to $\sim 500 \mathrm{Ma}$. These are from modified oscillatory-zoned zircon with the lower Th/U ratios.These yield younger ages of $\sim 36-37 \mathrm{Ma}$. These ages can represent the timing related to a metamorphic event.

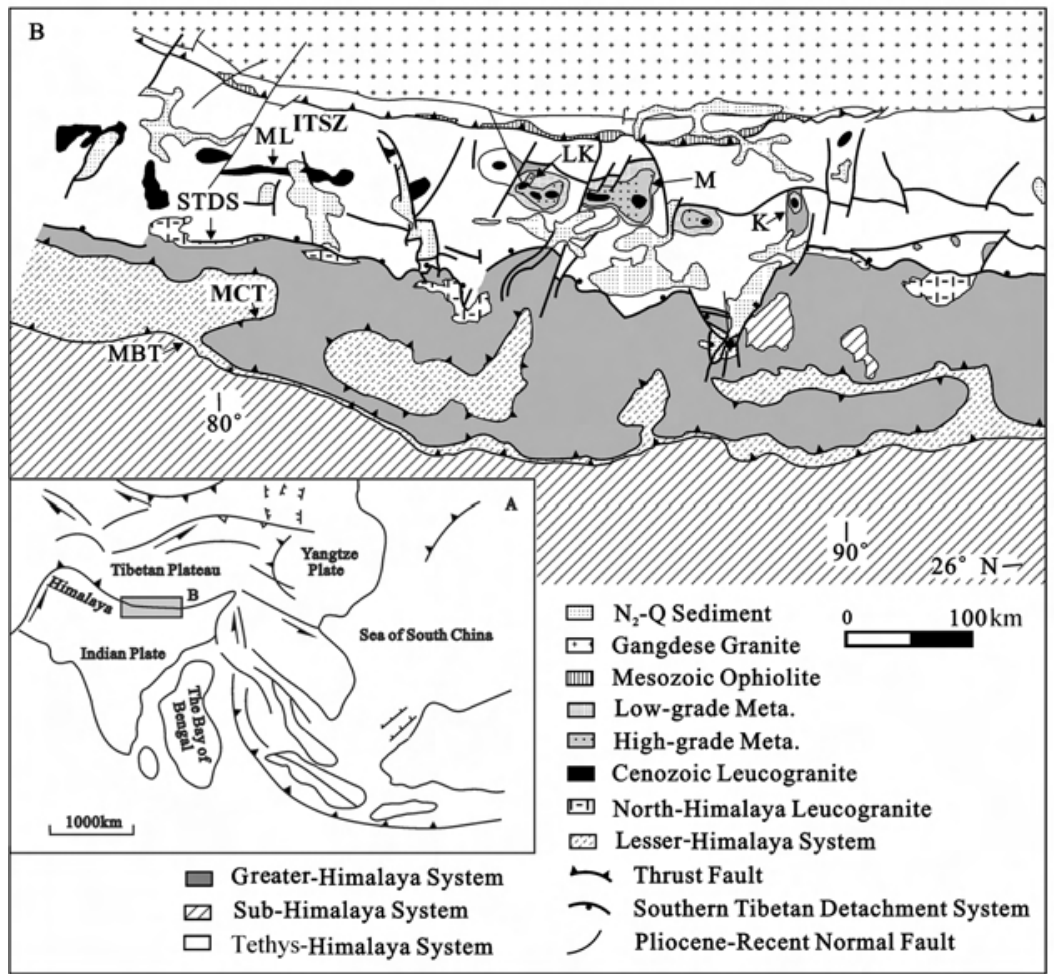

FIGURE 1. Regional tectonic setting of E-W-trending gneissic domes in southern Tibet. Abbreviations are as follows: K-Kangmar, M-Mabja, LK-Lagri-Kangri, ML-Malashan, ITSZ- Indus-Tsangpo Suture Zone, STDS-southern Tibetan Detchment System, MCT-Main Central Thrust fault, MBT-Main Boundary Thrust fault 
Malashan Dome

Sixteen zircon grains or fragments were analysedwith ages ranging from $\sim 28 \mathrm{Ma}$ to $\sim 500 \mathrm{Ma}$. Those having modified oscillatory-zoned zircon with the lower $\mathrm{Th} / \mathrm{U}$ ratios yield younger ages of $\sim 25-37 \mathrm{Ma}$. These ages can represent the timing related to a metamorphic event.

For samples from Malashan and Lagri-Kangri, both the cores and rims have different $U$ and Th contents. The rims have much lowerTh/U ratios $(<0.01)$, than the cores $(\mathrm{Th} / \mathrm{U}$ ratios $>0.1$ 1). We interpret the oscillatory-zoned zircon as primary zircon inherited from the parent granite rocks, similar to samples from Kangmar and Mabja. The rims of zircons of some grains suggest formation of new zircon overgrowths during amphibole facies metamorphism.

\section{Tectonic Interpretation and Discussion}

The southern Tibetan gneissic-domes are petrographically, geochemically and structurally similar to each other. Most of zircon grains from east, i.e. Mabja and Kangmar appear to be homogeneous in zoning patterns. These features, together with their high Th/U ratios, indicate an igneous origin. This study does not support the viewpoint that the gneissic domes are the injection or the diapir of the Cenozoic magmatic event. Our study confirms that these gneissic domes had igneous precursors formed during Neoproterozoic time (as Pan-African thermal event). The young ages recorded initial formation of the E-Wtrending gneissic domes, as well as the metamorphism of the southern Tibet. Moreover, this age can be referred as the peak time of crustal thickening in southern Tibet followed with the collision between Indian and Asian plates in the early Cenozoic time. This also indicates that the metamorphism is not at same time as the formation of the STDS, and also not at the same time as the injection of the leucogranite in southern Tibet. At the same time, this event also resulted in the re-metamorphism of the middle-lower crustal rocks.

Zircon features, Th/U ratios and ages indicate that these have different evolution or experienced various geologic events from east to west along this gneissic dome belt. Which kinds of mechanism or geologic events result in the differential ages of orthogneissic zircons, although they were covered by similar highgrade metamorphic rocks-by differential exhumation, uplift or adjoining of the fluid-remains speculative.

\section{Acknowledgement}

This research was supported by China National Basic Research Program Project (2002CB412601), Chinese NSF funds (49473171 and 40982024).

\section{References}

Burchfiel BC, ZL Chen, KV Hodges, YP Liu, LH Royden, CR Deng and JN Xu. 1992. The south Tibetan detachment system, Himalayan orogen: extension contemporaneous with and parallel to shortening in a collisional mountain belt. GSA Special Paper 269: 1-41

Lee J, BR Hacker, WS Dinklage, YWang, P Gans, A Calvert, JLWan, W Chen, AE Blythe and W McCleland. 2000. Evolution of the Kangmar dome, southern Tibet: structural, petrologic, and thermochronologic constraints. Tectonics 19: 872-895

Lee J, BR Hacker and YWang. in press. Evolution of north Himalayan gneiss domes: structural and metamorphic studies in Mabja Dome, southern Tibet. J Struct Geol 